\title{
PENGARUH WAKTU SIMPAN FILM PLASTIK BIODEGRADASI DARI PATI KULIT SINGKONG TERHADAP SIFAT MEKANIKALNYA
}

\author{
Fauzi Akbar, Zulisma Anita, Hamidah Harahap \\ Departemen Teknik Kimia, Fakultas Teknik, Universitas Sumatera Utara, \\ Jl. Almamater Kampus USU, Medan 20155, Indonesia \\ Email : fauzi.akbar1988@gmail.com
}

\begin{abstract}
Abstrak
Biodegradable plastik adalah plastik yang akan terurai di alam dengan bantuan mikroorganisme. Penggunaan pati sebagai bahan utama pembuatan plastik memiliki potensi yang besar karena di Indonesia terdapat berbagai tanaman penghasil pati. Untuk memperoleh bioplastik, pati ditambahkan dengan plastisizer gliserol, sehingga diperoleh plastik yang lebih fleksible dan elastis. Penelitian ini mengkaji tentang pemanfaatan pati kulit singkong dan gliserol sebagai bahan dasar pembuatan biodegradable plastik. Tujuan dari penelitian ini yaitu mengetahui pengaruh waktu penyimpanan terhadap sifat mekanik film plastik biodegradasi dari pati kulit singkong. Hasil yang diperoleh berupa lembaran tipis film plastik yang telah diuji sifat mekaniknya seperti kekuatan tarik, pemanjangan saat putus, dan elastisitasnya. Sifat mekanik dari film plastik akan menurun setiap minggunya dikarenakan adanya absorpsi uap air dan terjadi perpindahan plastisizer dalam matrik film plastis selama penyimpanan.
\end{abstract}

Kata kunci : biodegradable, pati kulit singkong, plastisizer

\begin{abstract}
Biodegradable plastics are plastics that will decompose in nature with the help of microorganisms. The use of starch as the main material of plastic manufacturing has great potential because in Indonesia there are different starch crops. To obtain bioplastics, starch is added to the plasticizer glycerol, in order to obtain a more flexible plastic and elastic. This study reviews the use of cassava starch and glycerol skin as a base for the manufacture of biodegradable plastics. The purpose of this research is to know the effect of storage time on the mechanical properties of plastic film biodegradation of starch cassava peel. The results obtained in the form of a thin sheet plastic film that have been tested mechanical properties such as tensile strength, elongation at break, and elasticity. Mechanical properties of plastic films will decrease every week due to the absorption of moisture and plasticizer migration occurs in a matrix of plastic films for storage.
\end{abstract}

Keywords : biodegradable, skin cassava starch, plasticizers

\section{Pendahuluan}

Saat ini ada banyak jenis bahan yang digunakan untuk mengemas makanan diantaranya adalah berbagai jenis plastik, kertas, fibreboard, gelas, tinplate dan aluminium [9].

Intensitas penggunaan plastik sebagai kemasan pangan makin meningkat. Hal ini disebabkan oleh banyaknya keunggulan plastik dibandingkan bahan kemasan yang lain. Plastik jauh lebih ringan dibandingkan gelas atau logam dan tidak mudah pecah. Bahan ini bisa dibentuk lembaran sehingga dapat dibuat kantong atau dibuat kaku sehingga bisa dibentuk sesuai desain dan ukuran yang diinginkan. Penggunaan plastik sebagai bahan pengemas menghadapi berbagai persoalan lingkungan, yaitu tidak dapat didaur ulang dan tidak dapat diuraikan secara alami oleh mikroba di dalam tanah, sehingga terjadi penumpukan sampah palstik yang menyebabkan pencemaran dan kerusakan bagi lingkungan. Kelemahan lain adalah bahan utama pembuat plastik yang berasal dari minyak bumi, yang keberadaannya semakin menipis dan tidak dapat diperbaharui. Seiring dengan persoalan ini, maka penelitian bahan kemasan diarahkan pada bahanbahan organik, yang dapat dihancurkan secara alami mudah diperoleh.

Sampah plastik rata-rata memiliki porsi sekitar $10 \%$ dari total volume sampah. Dari jumlah itu, sangat sedikit yang dapat didaur ulang. Padahal, sampah plastik berbahan polimer sintetik tidak mudah diurai organisme dekomposer. Butuh 300 - 500 tahun agar bisa terdekomposisi atau terurai sempurna. Membakar plastik pun bukan pilihan baik. Plastik yang tidak sempurna terbakar, di bawah $800{ }^{\circ} \mathrm{C}$, akan membentuk dioksin. Senyawa inilah yang berbahaya [10]. Untuk itu perlu adanya inovasi dalam pembuatan plastik yang ramah lingkungan. Menurut Syarief (1988) ada lima syarat yang dibutuhkan kemasan yaitu penampilan, perlindungan, fungsi, bahan dan biaya, serta penanganan limbah kemasan. 
Kulit singkong ini pada umumnya digunakan untuk pupuk kompos dan makanan ternak oleh masyarakat. Kandungan pati yang berasal dari kulit singkong yang cukup tinggi memungkinkan digunakan sebagai film plastik biodegradasi. Potensi tersebut dapat digunakan sebagai peluang untuk memberikan nilai tambah pada kulit singkong sebagai bahan dasar dalam pembuatan kemasan plastik yang ramah lingkungan [11].

\section{Teori}

Plastik merupakan polimer tinggi yang dibentuk dari proses polimerisasi. Menurut Shereve dan brink, plastik didefinisikan sebagai materi yang bahan utamanya adalah molekul organik yang terpolimerisasi dengan bobot molekul tinggi. Produk akhirnya padat, dan pada beberapa bagian tahap produksinya dapat dibentuk sesuai dengan yang diinginkan [8].

Bahan kemasan ini memiliki berbagai keunggulan yakni fleksibel (dapat mengikuti bentuk produk), transparan (tembus pandang), tidak mudah pecah, bentuk laminasi (dapat dikombinasikan dengan kemasan bahan lain) tidak korosif dan harganya relatif murah. Plastik biodegradable adalah plastik yang dapat digunakan seperti layaknya plastik konvensional, namun akan hancur terurai oleh aktivitas mikroorganisme menjadi air dan karbondioksida setelah habis terpakai dan dibuang ke lingkungan. Sifatnya yang dapat kembali ke alam, plastik biodegradasi merupakan plastik yang ramah lingkungan. Jepang telah menyepakati penggunaan nama plastik hijau (guriinpura) untuk plastik biodegradasi [5].

Berdasarkan bahan baku yang dipakai plastik biodegradable dibagi menjadi dua kelompok yaitu kelompok dengan bahan baku petrokimia seperti poli ( $\varepsilon$ - kaprolakton), (PCL) dan kelompok dengan bahan baku produk tanaman seperti pati dan selulosa. Jika kelompok pertaman menggunakan sumber daya alam yang tidak terbarukan (non renewable resources), maka yang kedua menggunakan sumber daya alam yang terbarukan [5]. Beberapa contoh yang mewakili polimer plastik biodegradable yang sudah diproduksi oleh skala industri ialah poli $(\varepsilon-$ kaprolakton). PCL adalah polimer hasil sintesis kimia menggunakan bahan baku minyak bumi. PCL mempunyai biodegradabilitas yang tinggi, dapat dihidrolisis oleh enzim lipase dan esterase yang tersebar luas pada tanaman, hewan dan mikroorganisme. Namun titik lelehnya yang rendah, $\mathrm{T}_{\mathrm{m}}=60{ }^{\circ} \mathrm{C}$ menyebabkan bidang aplikasinya menjadi terbatas. Adapun dari umbiumbian, pati dapat dihasilkan dari singkong, kentang. Selain dari kedua sumber tersebut, pati juga dapat dihasilkan dari batang tanaman, seperti pati sagu, dan dari daging buah muda seperti pisang. Pati umbi-umbian memiliki suhu gelatinisasi berkisar antara $70-80{ }^{\circ} \mathrm{C}$, bersifat elastis, mudah rusak dan memiliki penampakan yang translucent ketika dingin. Pati biji-bijian memiliki suhu gelatinisasi yang lebih tinggi, yaitu $95{ }^{\circ} \mathrm{C}$, berbentuk gel dan ketika dingin memiliki penampakan opaque [2].

Proses gelatinisasi pati menyebabkan perubahan viskositas larutan pati. Dengan menggunakan Brabender Viscoamylograph, terukur bahwa larutan pati sebelum dipanaskan memiliki viskositas 0 unit. Dengan adanya pemanasan, granula pati sedikit demi sedikit mengalami pembengkakan sampai titik tertentu. Pembengkakan pati diikuti dengan peningkatan viskositas. Semakin besar pembengkakan granula, viskositas semakin besar. Setelah pembengkakan maksimum, dan granula pati pecah dan pemanasan tetap dilanjutkan dengan suhu konstan, maka akan terjadi penurunan viskositas akibat proses degradasi [4].

Kulit umbi ubi kayu yang diperoleh dari produk tanaman ubi kayu (Manihot Esculenta Cranz) merupakan limbah utama pangan di negara-negara berkembang. Semakin luas areal tanaman ubi kayu diharapkan produksi umbi yang dihasilkan semakin tinggi yang pada gilirannya semakin tinggi pula limbah kulit yang dihasilkan. Setiap kilogram ubi kayu biasanya dapat menghasilkan $15-20 \%$ kulit umbi. Kandungan pati kulit ubi kayu yang cukup tinggi, memungkinkan digunakan sebagai pembuatan film plastik biodegradasi. Komponen kimia kulit singkong adalah sebagai berikut: protein $8,11 \%$, serat kasar $15,20 \%$, pektin $0,22 \%$, lemak kasar $1,44 \%$, karbohidrat $16,72 \%$, kalsium $0,63 \%$, air $67,74 \%$ dan abu 1,86 \% [12]. Sedangkan komponen kimia dan gizi daging singkong dalam $100 \mathrm{~g}$ adalah protein $1 \mathrm{~g}$, kalori $154 \mathrm{~g}$, karbohidrat $36,8 \mathrm{~g}$ dan lemak $0,1 \mathrm{~g}$. Selain itu kulit singkong juga mengandung tannin, enzim peroksida, glukosa, kalsium oksalat, serat dan $\mathrm{HCN}$ [7].

Pati merupakan senyawa polisakarida yang terdiri dari monosakarida yang berikatan melalui ikatan oksigen. Monomer dari pati adalah glukosa yang berikatan dengan ikatan $\alpha(1,4)$ glikosidik, yaitu ikatan kimia yang menggabungkan 2 molekul monosakarida yang berikatan kovalen terhadap sesamanya. Pati merupakan zat tepung dari karbohidrat dengan suatu polimer senyawa glukosa yang terdiri dari dua komponen utama, yaitu amilosa dan amilopektin. Polimer linier dari D-glukosa 
membentuk amilosa dengan ikatan ( $\alpha$ )-1,4glukosa. Sedangkan polimer amilopektin adalah terbentuk dari ikatan $(\alpha)$-1,4-glukosida dan membentuk cabang pada ikatan $(\alpha)-1,6-$ glukosida untuk plastik biodegradasi [5].

Plastisizer berfungsi untuk meningkatkan elastisitas dengan mengurangi derajat ikatan hydrogen dan meningkatkan jarak antar molekul dari polimer. Syarat plastisizer yang digunakan sebagai zat pelembut adalah stabil (inert), yaitu tidak terdegradasi oleh panas dan cahaya, tidak merubah warna polimer dan tidak menyebabkan korosi.

Karakteristik mekanik suatu film kemasan terdiri dari: kuat tarik (tensile strength), persen pemanjangan (elongation to break) dan elastisitas (elastic/young modulus). Parameter-parameter tersebut dapat menjelaskan bagaimana karakteristik mekanik dari bahan film yang berkaitan dengan struktur kimianya. Selain itu, juga menunjukkan indikasi integrasi film pada kondisi tekanan (stress) yang terjadi selama proses pembentukan film. Kuat tarik adalah gaya tarik maksimum yang dapat ditahan oleh film selama pengukuran berlansung. Kuat tarik dipengaruhi oleh bahan pemlastis yang ditambahkan dalam proses pembuatan film. Adapun persen pemanjangan merupakan perubahan panjang maksimum film sebelum terputus. Berlawanan dengan itu, adalah elastisitas akan semakin menurun jika seiring dengan meningkatnya jumlah bahan pemlastis dalam film.

Proses terjadinya biodegradasi film kemasan pada lingkungan alam dimulai dengan tahap degradasi kimia yaitu dengan proses oksidasi molekul, menghasilkan polimer dengan berat molekul yang rendah. Proses berikutnya (secondary process) adalah serangan mikroorganisme (bakteri, jamur dan alga) dan aktivitas enzim (intracellular, extracellular). Contoh mikroorganisme diantaranya bakteri phototrop, pembentuk endospora, gram negatif aerob. Umumnya kecepatan degradasi pada lingkungan limbah cair anaerob lebih besar dari pada limbah cair aerob, kemudian dalam tanah dan air laut. Permeabilitas suatu film kemasan adalah kemampuan melewatkan partikel gas dan uap air pada suatu unit luasan bahan pada suatu kondisi tertentu. Nilai permeabilitas sangat dipengaruhi oleh faktor-faktor sifat kimia polimer,, struktur dasar polimer, sifat komponen permanent. Umumnya nilai permeabilitas film kemasan berguna untuk memperkirakan daya simpan produk yang dikemas. Komponen kimia alamiah berperan penting dalam permeabilitas. Polimer dengan polaritas tinggi (polisakarida dan protein) umumnya menghasilkan nilai permeabilitas uap air yang tinggi dan permeabilitas terhadap oksigen rendah. Hal ini disebabkan polimer mempunyai ikatan hidrogen yang besar. Sebaliknya, polimer kimia yang bersifat non polar (lipida) yang banyak mengandung gugus hidroksil mempunyai nilai permeabilitas uap air rendah dan permeabilitas oksigen yang tinggi, sehingga menjadi penahan air yang baik tetapi tidak efektif untuk menahan gas [3].

Permeabilitas uap air merupakan suatu ukuran kerentanan suatu bahan untuk terjadinya proses penetrasi air. Permeabilitas uap air dari suatu film kemasan adalah laju kecepatan atau transmisi uap air melalui suatu unit luasan bahan yang permukaannya rata dengan ketebalan tertentu, sebagai akibat dari suatu perbedaan unit tekanan uap antara dua permukaan pada kondisi suhu dan kelembaban tertentu. Oleh karena itu permeabilitas dalam pembuatan film plastik biodegradasi berbasis pati sangat berpengaruh terhadap hasil akhir.

\section{Metodologi Penelitian}

Dalam proses pembuatan film plastik, terlebih dahulu dibuat bahan baku yaitu pati kulit singkong yang kering. Proses pembuatan pati kulit singkong diawali dengan cara membersihkan kulit singkong sebanyak 100 gram sehingga dihasilkan kulit singkong bersih dan putih. Setelah didapat kulit singkong yang bersih dan putih, tambahkan $100 \mathrm{ml}$ air yang berfungsi untuk mempermudah penghancuran. Proses penghancuran kulit singkong dilakukan dengan alat blender. Bubur kulit singkong yang telah didapat kemudian disaring dan dibiarkan selama 30 menit untuk mendapatkan endapan dari bubur kulit singkong. Jika sudah 30 menit endapan dipisahkan dari air, kemudian endapan yang diperoleh ditambahkan lagi dengan air dan diendapkan kembali dengan waktu yang sama yaitu 30 menit. Endapan yang didapat kemudian dikeringkan didalam oven dengan suhu $70{ }^{\circ} \mathrm{C}$ selama 30 menit. Setelah didapat pati kering dari persiapan bahan baku, untuk selanjtnya proses pembuatan film plastik biodegradable. Pati kulit singkong sebanyak 12 gram (divariasikan) dimasukkan kedalam beaker glass, kemudian ditambahkan dengan $25 \mathrm{ml}$.

Umumnya didapat campuran pati kulit singkong dengan air, tambahkan $3 \mathrm{ml}$ asam asetat (divariasikan) yang berfungsi sebagai pelarut dari campuran tersebut dan kemudian ditambahkan kembali $2 \mathrm{ml}$ gliserol (divariasikan) yang berfungsi sebagai plastizer yaitu membuat film plastik menjadi lebih elastis. Kemudian, campuran tersebut dipanaskan didalam waterbath 
selama 30 menit. Campuran ini akan berubah menjadi seperti lem, yang terus diaduk agar tidak menggumpal. Sembari diaduk, untuk menguji keasamannya masukkan kertas indikator, jika ternyata asam tambahkan dengan $\mathrm{NaOH} 0,1 \mathrm{ml}$ sampai netral. Angkat campuran yang telah mengental, kemudian dicetak diatas cetakan yang sebelumnya telah disiapkan yang terbuat dari polimer agar tidak lengket ketika diangkat. Dan tahap terakhir dikeringkan didalam suhu kamar sampai kering.

\section{Hasil dan Pembahasan}

Polimer biodegradasi mengalami perubahan sifat selama waktu penggunaan, dimana penuaan ini dapat membuat bahan ini tidak selalu cocok untuk digunakan secara komersial. Hal ini disebabkan oleh beberapa hal antara lain karena peristiwa fisis yang terjadi di dalamnya maupun pengaruh dari lingkungan, misalnya karena adanya perpindahan bahan tambahan (plastisizer) dalam plastik dan juga karena adanya pengaruh uap air dalam lingkungan penyimpanan [1]. Dalam penelitian ini, sampel terbaik yang di uji dilihat dari kekuatan tarik yang paling tinggi adalah pada 12 gram pati, $4 \mathrm{ml}$ gliserol dengan kekuatan tarik $0,2122 \mathrm{kgf} / \mathrm{mm}^{2}$. Film plastik disimpan pada suhu ruangan, 1 minggu sekali dilakukan uji kekuatan tarik terhadap film plastik tersebut.

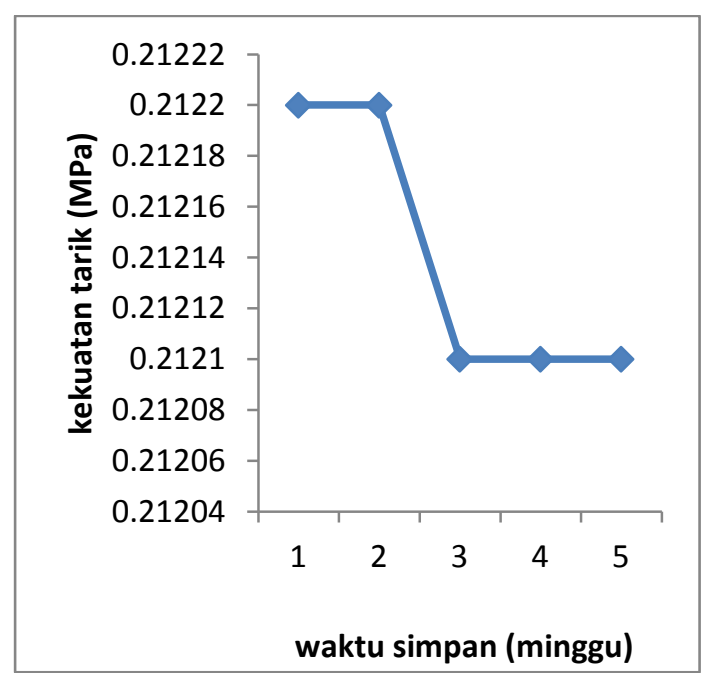

Gambar 1. Pengaruh Waktu Penyimpanan Terhadap Kekuatan Tarik Film Plastik Biodegradasi

Pada gambar 1 terlihat bahwa waktu penyimpanan tidak terlalu mempengaruhi kekuatan tarik. Dari gambar terlihat kekuatan tarik relatif konstan setiap minggunya. Dari minggu kedua ke minggu ketiga terjadi penurunan kekuatan tarik. Hal ini disebabkan adanya absorpsi uap air dan terjadi perpindahan plastisizer dalam matrik film plastik selama penyimpanan. Tetapi pada pada minggu keempat dan kelima kekuatan tarik konstan. Hal ini disebabkan film plastik biodegradasi tidak banyak dipengaruhi oleh adanya absorpsi uap air selama penyimpanan dan kemungkinan tidak terjadi perpindahan plastisizer gliserol dalam matriks film plastik [1].

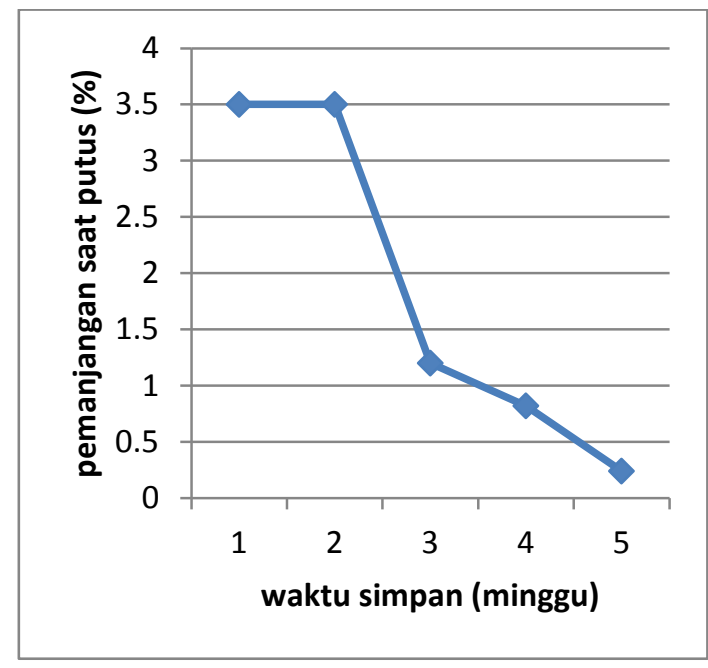

Gambar 2. Pengaruh Waktu Penyimpanan Terhadap Pemanjangan Saat Putus Pada Film Plastik Biodegradasi

Pada gambar 2 terlihat persen pemanjangan saat putus semakin berkurang setiap minggunya. Dimana pada minggu pertama dan kedua persen pemanjangan saat putus adalah sama dan menurun pada minggu ketiga dan terus menurun hingga minggu kelima. Hal ini menunjukkan pemanjangan saat putus film plastik hanya tahan 2 minggu. Hal ini diakibatkan gliserol yang menyebabkan fleksibilitas suatu plastik dipengaruhi oleh absorpsi uap air selama penyimpanan dan kemungkinan terjadi perpindahan plastisizer dalam matriks film plastik [5]. Penggunaan plastisizer yang terlampau banyak akan meningkatkan permeabilitas terhadap uap air. Hal ini sesuai dengan penelitian Ani Purwanti dengan judul Analisis kuat tarik dan elongasi plastik kitosan terplastisasi sorbitol, dimana hasil penelitian yang diperoleh adalah nilai elongasi film plastik mengalami penurunan selama penyimpanan [1]. 


\section{Kesimpulan}

Pada penelitian ini, penambahan gliserol pada pembuatan film plastik berpengaruh terhadap sifat mekanik film plastik. Sifat mekanik terbaik adalah pada berat pati 12 gram dengan penambahan volume gliserol $4 \mathrm{ml}$ dengan nilai kekuatan tarik $0,2122 \mathrm{kgf} / \mathrm{mm}^{2}$ dan pemanjangan saat putus sebesar $3,5 \%$ dengan waktu pemanasan selama 30 menit.Uji biodegradasi film plastik didalam tanah menyimpulkan bahwa film plastik terdegradasi dalam waktu 2 minggu (14 hari) di dalam tanah sehingga film plastik ini dikategorikan sebagai film plastik yang ramah lingkungan.Penambahan gliserol harus sesuai dengan berat pati agar sifat mekanik dari film plastik yang didapat optimal, jika ternyata terlalu banyak gliserol yang ditambahkan akan membuat film plastik akan cepat putus dan juga sebaliknya jika gliserol yang ditambahkan sedikit maka film plastik yang didapat akan mudah retak.

\section{Daftar Pustaka}

[1] Ani Purwanti, Analisis Kuat Tarik dan Elongasi Plastik Kitosan Terplastisasi Sorbitol, Institut Sains dan Teknologi AKPRIND, Penerbit Usaha Nasional, Surabaya, 1987.

[2] Dziendzic, S, The Technology of Starch Production, Blackie Academic, London, 1995.

[3] Firdaus, F, Sintetis Kemasan Film Ramah Lingkungan Dari Komposit Pati, Kitosan, dan Asam Polilaktat Dengan Pemplastis Gliserol, Pusat Sains dan Teknologi DPPM Universitas Indonesia, Yogyakarta, 2008.

[4] Philips, G, O dan Williams, Starch, Handbook of Hydrocoloids, CRC Press, London, 2000.

[5] Pranamuda, H, Pengembangan Bahan Plastik Biodegradable Berbahan Pati Tropis, Penerbit UI Press, Jakarta, 2003.

[6] Respati, Pengantar Kimia Organik Jilid I, Penerbit Aksara Baru, Jakarta, 1986.

[7] Rukmana, R, Ubi Kayu, Budidaya, dan Pasca Panen, Penerbit Kanisius, Jakarta, 1986.

[8] Shreve, Plastics, CRC Press, London, 1975.

[9] Syamsir, E, Plastik dan Senyawa Limonen, Penerbit UI Press, Jakarta, 2008.

[10] Syarif, E, Plastik dan Penggunaannya, Penerbit UI Press, Jakarta, 1988.

[11] Vedder, T, Edible Film, CRC Press, London, 2008.

[12]Winarno, F, Singkong dan Pengolahannya, Penerbit Aksara Baru, Jakarta, 1990. 